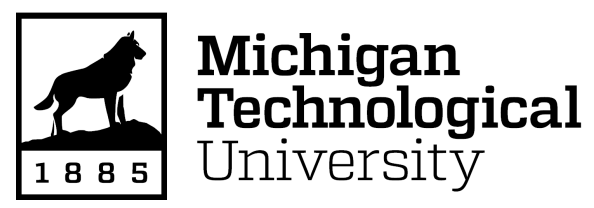

Michigan Technological University Digital Commons@ @ichigan Tech

\title{
Quantity and quality: unifying food web and ecosystem perspectives on the role of resource subsidies in freshwaters
}

\author{
Amy Marcarelli \\ Michigan Technological University \\ Colden V. Baxter \\ Idaho State University \\ Madeleine Mineau \\ Idaho State University \\ Robert O. Hall Jr. \\ University of Wyoming
}

Follow this and additional works at: https://digitalcommons.mtu.edu/biological-fp

Part of the Life Sciences Commons

\section{Recommended Citation}

Marcarelli, A., Baxter, C. V., Mineau, M., \& Hall, R. O. (2011). Quantity and quality: unifying food web and ecosystem perspectives on the role of resource subsidies in freshwaters. Ecology, 92(6), 1215-1225. http://dx.doi.org/10.1890/10-2240.1

Retrieved from: https://digitalcommons.mtu.edu/biological-fp/15

Follow this and additional works at: https://digitalcommons.mtu.edu/biological-fp

Part of the Life Sciences Commons 


\title{
Quantity and quality: unifying food web and ecosystem perspectives on the role of resource subsidies in freshwaters
}

\author{
Amy M. Marcarelli, ${ }^{1,2,4}$ Colden V. Baxter, ${ }^{1}$ Madeleine M. Mineau, ${ }^{1}$ and Robert O. Hall, Jr. ${ }^{3}$ \\ ${ }^{1}$ Stream Ecology Center, Department of Biological Sciences, Idaho State University, Pocatello, Idaho 83209 USA \\ ${ }^{2}$ Department of Biological Sciences, Michigan Technological University, Houghton, Michigan 49931 USA \\ ${ }^{3}$ Department of Zoology and Physiology, University of Wyoming, Laramie, Wyoming 82071 USA
}

\begin{abstract}
Although the study of resource subsidies has emerged as a key topic in both ecosystem and food web ecology, the dialogue over their role has been limited by separate approaches that emphasize either subsidy quantity or quality. Considering quantity and quality together may provide a simple, but previously unexplored, framework for identifying the mechanisms that govern the importance of subsidies for recipient food webs and ecosystems. Using a literature review of $>90$ studies of open-water metabolism in lakes and streams, we show that high-flux, low-quality subsidies can drive freshwater ecosystem dynamics. Because most of these ecosystems are net heterotrophic, allochthonous inputs must subsidize respiration. Second, using a literature review of subsidy quality and use, we demonstrate that animals select for high-quality food resources in proportions greater than would be predicted based on food quantity, and regardless of allochthonous or autochthonous origin. This finding suggests that low-flux, high-quality subsidies may be selected for by animals, and in turn may disproportionately affect food web and ecosystem processes (e.g., animal production, trophic energy or organic matter flow, trophic cascades). We then synthesize and review approaches that evaluate the role of subsidies and explicitly merge ecosystem and food web perspectives by placing food web measurements in the context of ecosystem budgets, by comparing trophic and ecosystem production and fluxes, and by constructing flow food webs. These tools can and should be used to address future questions about subsidies, such as the relative importance of subsidies to different trophic levels and how subsidies may maintain or disrupt ecosystem stability and food web interactions.
\end{abstract}

Key words: ecosystem metabolism; flow food web; freshwater; gross primary production; lake; openwater metabolism; resource subsidy; secondary production; stream; trophic interaction.

\section{INTRODUCTION}

Ecosystems are connected by flows of organisms, energy, and nutrients, commonly referred to as resource subsidies (Polis et al. 1997, Power and Rainey 2000, Reiners and Driese 2001). Studies demonstrated decades ago that subsidy materials could dominate ecosystem budgets and strongly affect within-ecosystem dynamics (Fisher and Likens 1973, Webster and Meyer 1997). More recently, ecologists have shown that subsidies of prey may have dramatic consequences for food webs in

Manuscript received 19 November 2010; revised 17 February 2011; accepted 22 February 2011. Corresponding Editor: J. J. Stachowicz.

${ }^{4}$ Present address: Department of Biological Sciences, Michigan Technological University, 1400 Townsend Drive, Houghton, Michigan 49931 USA. E-mail: ammarcar@mtu.edu recipient habitats, supporting animal production and influencing cascading trophic effects (Polis et al. 1997, Nakano and Murakami 2001, Polis et al. 2004). Although ecosystem and food web ecology have converged on studies of subsidies, the dialogue over their importance is clouded by the fact that some have described their importance in food web terms (e.g., animal population dynamics, trophic pathways, interaction strengths), whereas others have used ecosystem terms (e.g., budgets and flows of carbon or nutrients). Using these approaches together has yielded powerful insight on classic ecological questions and has raised new questions that provide promise for advancing ecological theory (Lindeman 1942, Wiegert and Owen 1971, de Ruiter et al. 1995). The goal of this paper is to demonstrate how merging measures of subsidy quality and quantity and tools from ecosystem and food web 
ecology can further unify our current understanding of the significance of resource subsidies.

There is a long history of subsidy research in lakes and streams, perhaps because the characteristics of these ecosystems lead to conspicuous and often high-magnitude subsidy fluxes. Although subsidies flow into and out of all ecosystems, inputs to lakes and streams tend to be much larger than their reciprocal flows to adjacent terrestrial ecosystems because of the position of lakes and streams at convex locations in the landscape, and because they are linked through watersheds by the downhill flow of water (Hynes 1975, Jackson and Fisher 1986, Leroux and Loreau 2008, Winter and Likens 2009). Stream ecologists have long studied the role of allochthonous (originating from outside) and autochthonous (originating from inside) food sources for invertebrates and fishes (Minshall 1967, Cummins 1974, Allan 1981) and net ecosystem energy balances (Fisher and Likens 1973, Minshall 1978), and studies of their relative contributions have led to a 30 -year debate regarding the degree to which streams are net autotrophic (internal gross primary production, or GPP, exceeds ecosystem respiration, or ER) or net heterotrophic (internal GPP is less than ER). Likewise, ecologists are currently demonstrating that lake ecosystems are closely linked to adjacent terrestrial ecosystems by flows of dissolved and particulate organic carbon (DOC and POC; Pace et al. 2004). These allochthonous flows can drive microbial respiration rates much greater than those supported by in-lake GPP alone, leading to the conjecture that many lakes, and perhaps most freshwater ecosystems, are net heterotrophic (Duarte and Prairie 2005).

Subsidies vary widely in their quality and quantity, leading to variation in their relative importance across trophic levels and among different habitats. Ecosystem studies have typically focused on the quantity of a subsidy and have ascribed importance to large subsidy fluxes, such as riparian leaf-fall into streams or watershed DOC input to lakes (Fisher and Likens 1973, Caraco and Cole 2004). However, the way in which these subsidies are processed in the receiving habitats will depend on their quality, which is essentially determined by the chemical characteristics of a resource (i.e., carbon to nutrient ratios, structure and lability or recalcitrance of the carbon molecules). Operationally, food quality is expressed or determined as caloric content, nutrient and lipid content, structure of carbon molecules, stoichiometry, or other measures of chemical characteristics (Gerking 1994, Lau et al. 2008, Brett et al. 2009). However, resource quality also depends on emergent properties related to animal needs and flexibility, including assimilation efficiency, flexibility of feeding behavior, and timing of resource availability relative to other food resources (Gerking 1994, Wipfli and Baxter 2010, Yang et al. 2010). Yet, quality and quantity are complementary properties, and together may lead to food web and ecosystem effects that would not be predicted by focusing on either in isolation. For example, DOC from watersheds might represent the largest subsidy to streams and lakes, but this food is often low in quality, and therefore may be selected against by animal and microbial consumers (Reynolds 2008). In contrast, prey fluxes such as terrestrial invertebrate input to streams may be small fluxes, but may be selected for as high-quality food by stream fish because of the large size of individual prey and quality relative to in situ prey (Baxter et al. 2005). Although the idea of merging perspectives on food quality and quantity is not new, considering how these characteristics govern the role of subsidies for recipient food webs and ecosystems may provide a simple, previously unexplored framework for comparing and contrasting diverse subsidies to freshwaters.

We test the central hypothesis that the impact of trophic subsidies in recipient habitats is dictated by both quantity and quality. First, through a review of $>90$ lake and stream studies, we demonstrate that the quantity of a subsidy drives ecosystem dynamics, showing that ecosystem metabolism in both lakes and streams is typically net heterotrophic, and therefore must be fueled by large fluxes of subsidies, regardless of the quality of the subsidy. Next, we demonstrate the importance of subsidy quality through a second literature synthesis showing that stream and lake animals select for high-quality food resources, regardless of their relative abundance and their allochthonous or autochthonous origin. Finally, we outline approaches and metrics that may resolve this apparent contradiction by merging food web and ecosystem perspectives. We illustrate the efficacy of these approaches via a series of analyses, syntheses, and case studies.

\section{Subsidy Quantity and Ecosystem Metabolism}

Ecosystem metabolism is a synthetic descriptor of the sources and sinks of organic matter that can be used as a measure of how ecosystems respond to subsidies (Odum and Barrett 2005). Early freshwater ecologists showed that terrestrially derived leaf litter dominated the organic matter budgets of forested headwater streams, and that decomposition of this high-abundance, lowquality material by bacteria, fungi, and other detritivores leads to net heterotrophic metabolic balances for such stream ecosystems (Fisher and Likens 1973, Mulholland 1981). Because the vast majority of streams receive large inputs of terrestrial organic matter (Webster and Meyer 1997), ecologists generalized that most streams are heterotrophic. Yet, they also acknowledged that high-quality autochthonous production could cause net autotrophy in ecosystems where production rates were high, such as spring-fed and desert streams (Odum 1957, Minshall 1978). More recently, detailed seasonal measurements of open-water metabolism in streams have demonstrated that even forested streams, which are 
strongly heterotrophic on an annual scale, have peaks of GPP and periods of net autotrophy during times of high light availability (Roberts et al. 2007). In contrast, the paradigm of lakes as "closed systems" and a focus on phytoplankton inspired a widespread assumption that lakes are autotrophic (Wetzel 2001). However, a consideration of bacterial processes demonstrated that ER can exceed GPP in the pelagic zone of lakes (del Giorgio and Peters 1993, Wetzel 1995). Moreover, recognition of the importance of littoral zone and benthic metabolism (Cole et al. 2000, Vadeboncoeur et al. 2001), and results of whole-lake carbon isotope enrichments (Pace et al. 2004), have demonstrated that many lakes receive large subsidies of terrestrially derived carbon that can cause high bacterial respiration rates and net heterotrophic metabolic balances. Therefore, an ongoing area of investigation is the prevalence and degree to which both lake and stream ecosystems are net heterotrophic, and thus reliant on allochthonous subsidies to support their metabolism.

To test the hypothesis that terrestrial subsidies may drive ecosystem metabolism in lakes and streams, we conducted a literature review of freshwater metabolism estimates obtained using only open-water techniques (Odum 1956, Cole et al. 2000), which integrate metabolism from all habitats at the scale of a whole lake or stream reach. The results of this synthesis show that daily estimates of ER exceed GPP in most freshwater ecosystems for which estimates are presently available (91 studies, 264 lakes and streams; Appendix A: Table A1; see also Plate 1). For streams, the median ratio of production to respiration (GPP:ER) measured by the open-water technique was $0.50 \pm 0.42 \mathrm{SD}$ (range $0.002-2.65, n=229$; Fig. 1). In lakes, the median GPP:ER was $0.6 \pm 0.34 \mathrm{SD}$ (range $0.09-1.3, n=35$; Fig. 1). For streams, GPP:ER was positively related to discharge, latitude, and concentrations of nitrate and phosphate, whereas in lakes, GPP:ER was positively related to lake area and epilimnion depth, although all of these relationships were weak $\left(r^{2}=0.04-0.16\right.$; Appendix A: Figs. A1-3). This synthesis confirms the now widely accepted paradigm that most aquatic ecosystems are net heterotrophic because of high ER rates driven by microbial production, and that these must be driven by large fluxes of allochthonous materials into streams and lakes. Yet, it is unclear to what extent this same flux of allochthonous material may be preferentially incorporated into freshwater food webs and animal production.

To understand the extent to which allochthonous carbon may or may not fuel food webs, it is necessary to examine the pathways and fates of carbon within ecosystems, which cannot be directly inferred from ecosystem metabolism measurements. Microbial respiration of allochthonous carbon drives ecosystem metabolism, GPP:ER, and net $\mathrm{CO}_{2}$ efflux in both lakes and streams (Meyer 1989, del Giorgio et al. 1999). Yet, in a series of small lakes with GPP:ER $<1$,

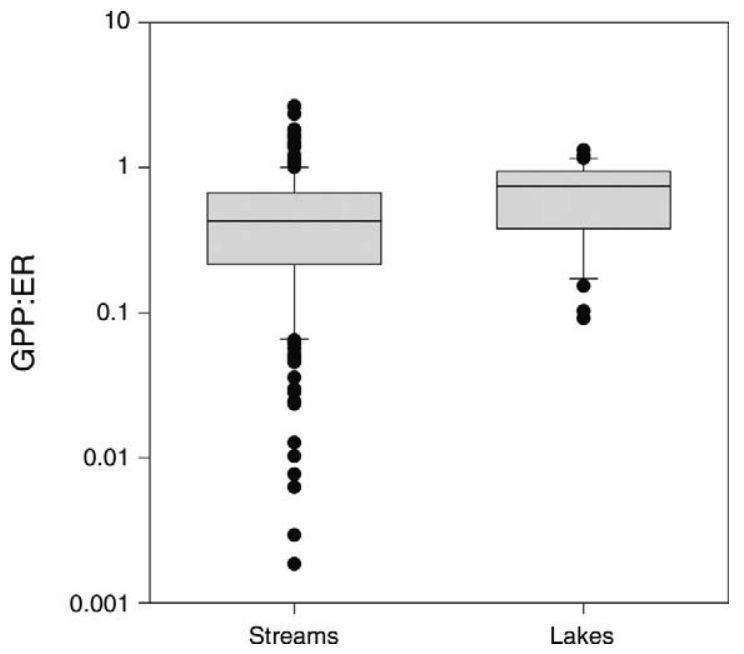

FIG. 1. Ratios of gross primary production to ecosystem respiration (GPP:ER) measured using the open-water technique in streams $(n=229)$ and lakes $(n=35)$ show that most aquatic ecosystems have a net heterotrophic metabolic balance. On the box and whisker plots, the bottom box line indicates the 25 th percentile, the internal line indicates the median, and the top line indicates the 75 th percentile. The whiskers indicate the 90 th and 10th percentiles, and dots indicate values that fall outside the 90 th and 10th percentiles.

terrestrial C supported $13-43 \%$ of total lake ER, so that even in heterotrophic lakes, more than $50 \%$ of the carbon respired was of autochthonous origin (Cole et al. 2000). Moreover, autochthonous material may fuel production of some animals even in an ecosystem with a net heterotrophic metabolic balance, and vice versa (Minshall 1978, Finlay 2001, McCutchan and Lewis 2002). For example, in unproductive heterotrophic lakes, Karlsson (2007) found that allochthonous inputs fueled $80 \%$ of bacterial respiration, but only $40 \%$ of zooplankton production. An autochthonous-based community of animals or microbes is one in which at least $50 \%$ of the organic matter consumed or processed is from autochthonous sources, and similarly for allochthonous sources, regardless of GPP:ER (Rosenfeld and Mackay 1987). To address this issue, Rosenfeld and Mackay (1987) suggested that streams should be classified using the ratio of invertebrate production based on allochthonous and autochthonous materials, while Dodds and Cole (2007) suggested grouping ecosystems into heterotrophic and autotrophic states using GPP and ER as independent classifiers. However, the former suggestion fails to address fluxes at the ecosystem level (i.e., it classifies based on one consumer group, animals; see critique by Meyer 1989), while the latter does not reconcile observations of consumer organic matter pathways that depart from expectations based on ecosystem-level carbon fluxes. To truly overcome these limitations, approaches are needed that combine patterns of animal and microbial consumption with energy flow in a comprehensive framework. 

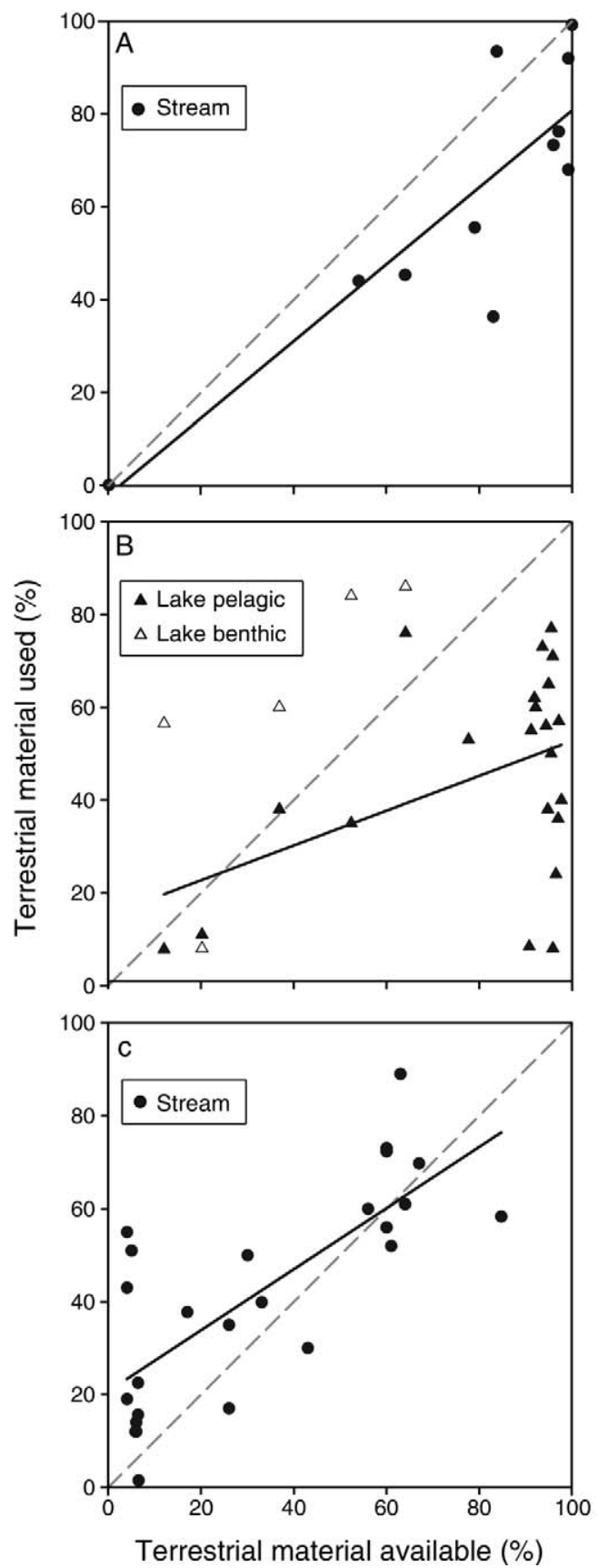

FIG. 2. Availability of terrestrial subsidies vs. use by animals in streams and lakes. The dashed line in all panels is the 1:1 line, where food resources are used in proportion to their availability (A) Terrestrially derived coarse and fine particulate organic matter (predominately leaves) are used in lower proportion vs. their availability by stream macroinvertebrates. (B) Terrestrially derived particulate and dissolved organic $\mathrm{C}$ are used in lower proportion than their availability by zooplankton (closed triangles), but in greater proportion by benthic lake macroinvertebrates (open triangles). (C) Stream fish use terrestrial invertebrate prey in greater proportion than their availability, but this relationship is close to the $1: 1$ line.

\section{Subsidy Quality and Food Web Pathways}

Considering the effects of subsidies only at the ecosystem level (e.g., open-water metabolism) ignores the fact that the strength of the effect of a subsidy depends not only on its flux, but also on its quality relative to in situ food resources (Baxter et al. 2005, Marczak et al. 2007, Wipfli and Baxter 2010). For example, terrestrial invertebrates may support a large proportion of the diet and production of stream fishes like salmonids, despite low availability during much of the year, because their large size relative to benthic prey make them an energetically preferable prey item, and because they may be easy targets for drift-feeding fish (Wipfli 1997, Nakano et al. 1999, Baxter et al. 2005). In contrast, although leaf litter input dominates the food resources available to many stream macroinvertebrates, algal carbon may be a key resource because of its lability in comparison to litter (Junger and Planas 1994, Thorp and Delong 1994, McCutchan and Lewis 2002). Indeed, leaf litter is of such poor quality that invertebrates rely on microbial and fungal detritivores to increase the nutrient content and palatability of this material before it can be efficiently assimilated (Webster and Benfield 1986).

To test the hypothesis that animals select for highquality food resources regardless of allochthonous or autochthonous origin, we conducted a second literature review. We examined published studies reporting use (consumption from diets or assimilation inferred from isotopic composition of tissues) and availability (relative proportion of standing stocks or available prey) of two different resource subsidies relative to in situ resources: "low"-quality leaf material and DOC vs. autochthonous primary producers for aquatic invertebrates (excluding predators), and "high"-quality terrestrial invertebrates vs. aquatic macroinvertebrates for invertivorous fish (Appendix B: Table B1). We predicted that high-quality subsidies would be selected for by consumers relative to their availability, while low-quality subsidies would be selected against.

Our review revealed selection for or against terrestrially derived organic matter in both lakes and streams, and this preference appeared to be mediated both by the quality of the terrestrial subsidy and the characteristics of the animals. Stream macroinvertebrates and lake zooplankton both selected strongly against terrestrial organic matter (Fig. 2A, B), with the percentage of allochthonous material used by these animals being lower than the percentage available in $91 \%$ of lakes and streams, and significant linear relationships with slopes $<1$ : stream invertebrate percentage use $=(0.8 \times$ percentage available $)-2.0\left(F_{1,10}=42.8, P<0.0001\right)$; lake zooplankton percentage use $=(0.4 \times$ percentage available $)+15.2\left(F_{1,20}=4.7, P=0.04\right)$. This finding suggests that both groups of animals select for highquality autochthonous materials when feeding. In contrast, lake benthic macroinvertebrate use of allochthonous material was not significantly related to 

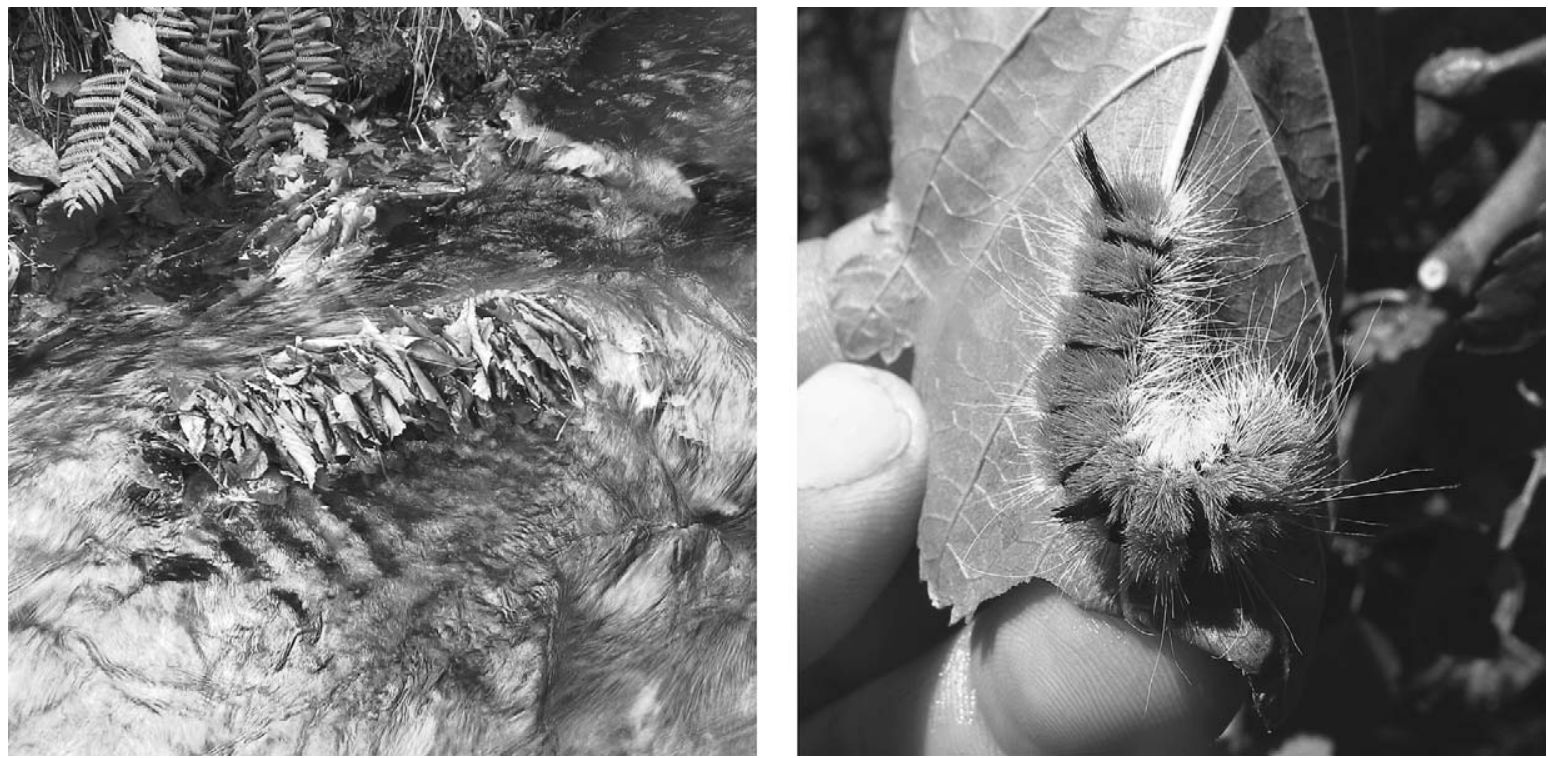

Plate 1. Terrestrial subsidies to freshwaters may have contrasting qualities compared to in situ food resources. In streams, leaf material (left) tends to be a low-quality food resource for aquatic macroinvertebrates relative to autochthonous primary producers. In contrast, terrestrial invertebrates like caterpillars (right) may be high-quality food resources for invertivorous fish relative to benthic aquatic macroinvertebrates. Photo credits: left, A. M. Marcarelli; right, C. V. Baxter.

availability, although use of allochthonous material generally exceeded availability (Fig. 2B). However, this pattern should be interpreted with caution, because all lakes where benthic macroinvertebrates preferentially used terrestrial material were small, with low benthic primary production. When nutrient enrichment in one of these lakes stimulated benthic primary production, consumption of terrestrial carbon by benthic invertebrates decreased from $86 \%$ to $9 \%$ (Cole et al. 2006). For invertivorous stream fishes, the use of high-quality terrestrial prey exceeded its availability in $72 \%$ of the studies, and use vs. availability were linearly related, with a slope $<1$ (Fig. 2C; percentage use $=(0.6 \times$ percentage available) $\left.+20.7 ; F_{1,23}=30.4, P<0.0001\right)$. However, all of the study points clustered strongly around the 1:1 line, and a number of studies fell below the line, probably because availability of terrestrial prey varies strongly with habitat and season. This relationship also could be affected by the methods used to determine availability of terrestrial vs. aquatic prey, which included drift densities, pan traps, and benthic surber sampling, as well as variation in the palatability of terrestrial invertebrate inputs (Gerking 1994).

In general, this synthesis supports the hypothesis that animals in streams and lakes do not select food resources based strictly on their availability, but rather may select for high-quality foods regardless of origin within (autochthonous algal material) or external to (terrestrial invertebrates) the ecosystem of interest. However, comparisons of animal diets to standing stocks, although woefully rare in the literature, do not tell us which resource subsidies influence both food web pathways and net ecosystem dynamics. To take this next step, we need approaches that consider how food quality controls flows between producers and consumers, while retaining the ecosystem context of subsidy quantity and organic matter fluxes.

\section{Merging Approaches to Understand Subsidies}

We have demonstrated that the ecosystem and food web effects of a subsidy depend on its quality and its quantity, yet the role of subsidies cannot be understood via either of these characteristics by themselves. When measures of food quality, selection, and ecosystem fluxes have been combined, ecologists have gained the greatest insight into how subsidies may drive spatial and temporal dynamics of ecosystems and food webs. Some ways that these have been, or may be, integrated include (1) combining food web dynamics with organic matter standing crops and budgets, (2) comparing measurements of production (primary, secondary, and fish) with ecosystem fluxes, and (3) calculating energy or organic matter flow along food web pathways to create flow food webs. These approaches are not mutually exclusive, and the most compelling studies include some combination or subset of them. Moreover, these approaches can and should be integrated with measures of subsidy quality (e.g., stoichiometry or fatty acids; Lau et al. 2008, Brett et al. 2009) to provide independent measures of food quality, consumer selection and consumption, and organic matter production and flux.

The idea of merging ecosystem and food web measures to describe energy or organic matter flow through ecosystems is not new, but perhaps has been hamstrung by the singular, overly complex approaches that have been taken in the past. Classic studies like 
those of Cedar Bog Lake (Lindeman 1942) and Silver Springs (Odum 1957) provided a framework for ecologists to describe energy flow through food webs. These early successes inspired large, coordinated studies like those during the International Biological Program (IBP) that strove to describe energy flow through food webs and ecosystems and develop complex models underpinned by mechanistic equations, based on detailed, site-specific parameterization and calibration (Hagen 1992, Golley 1993). The many physiological, population, and food web measurements needed for this approach made it difficult to undertake (Hagen 1992), and the simultaneous success of budget studies for advancing ecosystem understanding (Fisher and Likens 1973, Likens and Bormann 1995) and experimental studies for understanding food web dynamics (Paine 1980, Bender et al. 1984) led some researchers to sharply criticize the food web-energy flow approach (Paine 1980), and others to simply abandon it as too timeconsuming and difficult. Our perspective is that studies that integrate the broad ideas of energy and organic matter flow and food web dynamics do not necessarily require a return to such empirically intensive, bottom-up model construction efforts. Rather, comparisons of ecosystem pools, production, and fluxes to characteristics of food webs are a simple, yet powerful, way to integrate food web and ecosystem information (e.g., Thorp and Delong 2002, Vander Zanden and Vadeboncoeur 2002). In the study of subsidies, the power of this approach has been demonstrated through a variety of insightful, often experimental, studies that combine measurements of subsidy fluxes, organic matter and consumer standing stocks, production at multiple trophic levels, food web linkages, and ecosystem-level processes (Appendix C).

\section{Investigating food web subsidies in the context of ecosystem budgets}

The simplest studies that combine food web and ecosystem approaches use traditional techniques for measuring food web or ecosystem characteristics, but do so in an integrated way. A very simple example is the terrestrial food use vs. availability synthesis that we have already described (Subsidy quality and food web pathways; see Appendix B). In that analysis, if we had simply examined the food use patterns of stream macroinvertebrates, we would conclude, as many before us have, that allochthonous material is the most important food resource to stream invertebrates because it comprises an average of $60 \%$ of material consumed across all streams. Yet, comparing these consumptions to availability of these materials demonstrated that stream invertebrates, in fact, disproportionately use autochthonous material, suggesting that resource quality and animal preference control the manner and degree to which subsidies are used in recipient food webs. Despite the simplicity of these comparisons, it is striking how often ecosystem or food web evidence is used while completely excluding complementary information from the other subfield. For our food use vs. availability synthesis, we could only locate data for 11 streams where both invertebrate use and availability of subsidies were reported, and they were sometimes reported in separate papers (Appendix B: Table B1). As a result, ecologists have clearly demonstrated that stream organisms use both allochthonous and autochthonous organic matter to build their biomass, but we can rarely estimate the extent to which these materials support organism production or organic matter flux through food webs (but see Appendix C).

Placing subsidies into the context of an organic matter budget may in some cases reveal that subsidies that appear insignificant at the ecosystem level may be essential regulators of trophic energy flux. For example, the flux of terrestrial invertebrate input to Horonai Stream, Hokkaido, Japan amounts to only $5 \%$ of the carbon contributed by the leaf litter subsidy annually (Nakano and Murakami 2001, Shibata et al. 2001). Despite the low magnitude of the terrestrial invertebrate flux, when terrestrial invertebrate inputs were experimentally suppressed, fish growth decreased $31 \%$ and biomass decreased 50\% (Kawaguchi et al. 2003, Baxter et al. 2007). The flux of terrestrial invertebrates peaks during the summer months and is temporally separated from in situ prey production (which is lowest during the summer), and therefore stabilizes food resources for stream fishes (Nakano and Murakami 2001, Takimoto et al. 2003). Moreover, Nakano and Murakami (2001) extended their analysis to the scale of trophic fluxes, estimating that terrestrial invertebrate subsidies contributed $44 \%$ to the annual energy budget of the fish assemblage. The next step in this stream, which has not yet been taken, is to place this fish production estimate into a whole-ecosystem context by comparing it to ecosystem-level fluxes (i.e., metabolism), and examining the magnitude of this subsidy flux in comparison to fluxes at different trophic levels and organic matter flow along other food web pathways.

\section{Using ecosystem and trophic production and fluxes to quantify subsidy impacts}

A next step for merging ecosystem and food web approaches to the study of subsidies is to repeatedly measure organic matter or organism standing stocks, and integrate them across time to estimate production, fluxes, and trophic efficiencies. Fluxes that seem extraordinarily high when measured at a single trophic level may appear insignificant when compared to ecosystem-level fluxes. One example of such an analysis, although not specifically focused on subsidies, was conducted by Hotchkiss and Hall (2010), who studied an invasive freshwater snail with extremely high rates of secondary production in a Wyoming stream (Appendix D). Although this snail had tremendously high rates of biocalcification, this biocalcification contributed only $7 \%$ of the net daily $\mathrm{CO}_{2}$ flux from the stream, with the rest of the flux being driven by ER. 
Comparing production rates at a single trophic level to whole-ecosystem fluxes may identify the relative contribution of subsidies to trophic level dynamics. For example, our analysis of open-water metabolism suggested that allochthonous subsidies drive heterotrophic activity, measured as ER, in streams (Subsidy quantity and ecosystem metabolism; Appendix A). In turn, one may hypothesize that secondary production should be positively related to ER in streams, as they are both measures of heterotrophic activity. To test this hypothesis, we compiled rates of secondary production, ER, and GPP:ER for streams and lakes where all three had been measured (Fig. 3; Appendix D: Table D1). In streams, secondary production did increase as ER increased, but they were not significantly related (Fig. $\left.3 \mathrm{~A} ; F_{1,12}=0.7, \quad P=0.4\right)$. However, secondary production was significantly positively related to GPP:ER (Fig. 3B, log[secondary production] $=0.46 \times$ $\log [$ GPP:ER $\left.]-1.46 ; r^{2}=0.41, F_{1,12}=8.4, P=0.01\right)$. In lakes, we could only find two lakes where secondary production and GPP:ER had been measured, which precluded linear regression analysis, but when plotted, they fit the general pattern of the stream data set (Fig. 3). This simple comparison suggests that ER in streams is not adequate to predict production at higher trophic levels, and supports our earlier argument that autochthonous production may disproportionately support animal production in streams. Moreover, this finding points to a potential decoupling between bulk carbon flow, measured as ER, and animal productivity, which may be a common characteristic of heterotrophic ecosystems.

Of course, this analysis, like many of the others we have presented here, is limited in its inference by the fact that the measurements that we compiled were made at different spatial and temporal scales and intensities. To fully address potential relationships between wholeecosystem fluxes, trophic-level production, and subsidy quality, comprehensive empirical studies must be undertaken that integrate these metrics and measure them at similar spatial and temporal scales. One of the best examples of this comprehensive approach is a series of whole-lake experiments, where ${ }^{13} \mathrm{C}$ labeling of autochthonous production demonstrated that 28-68\% of the carbon respired by pelagic bacteria and comprising bacterial biomass was derived from terrestrial sources, although bacteria preferred carbon from autochthonous sources (Kritzberg et al. 2004, Cole et al. 2006). Food web models based on the experimental results showed that terrestrial organic carbon supplied $33-73 \%$ of carbon flow to zooplankton and $20-50 \%$ of carbon flow to fishes (Pace et al. 2004, Carpenter et al. 2005, Cole et al. 2006). The allochthonous organic matter subsidy was transferred to predators by zooplankton and benthic invertebrate consumption of terrestrial POC, while little of the carbon assimilated by bacteria was passed to invertebrates (Cole et al. 2006). These experiments have provided a number of
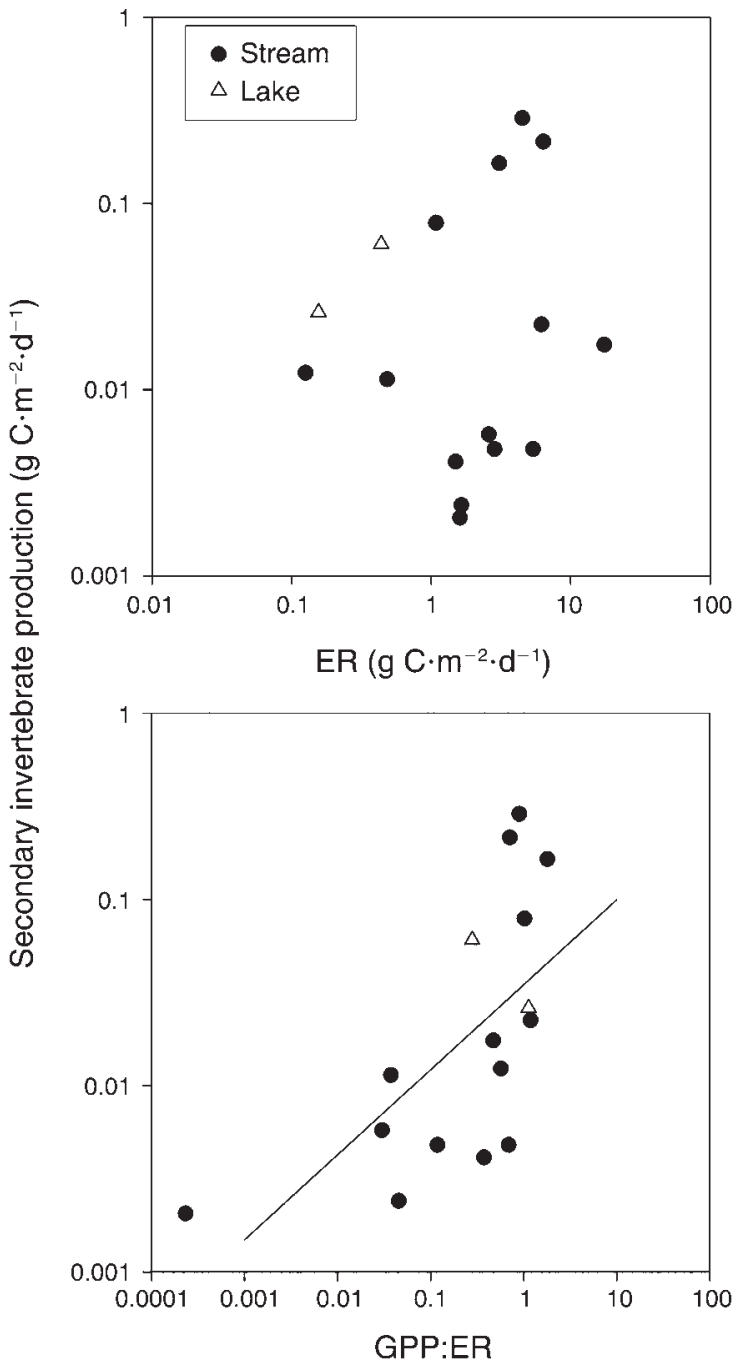

FIG. 3. Secondary invertebrate production in streams (solid circles) is (A) unrelated to measures of ecosystem respiration, or ER, but (B) positively related (solid line) to the ratio of gross primary production to ER (GPP:ER). Too few estimates of secondary production and GPP:ER exist to evaluate these patterns for lakes (open triangles), but the few existing data points follow a similar pattern as in streams.

insights into the contribution of allochthonous subsidies (particularly POC) to food webs in small lakes. Moreover, they suggest that microbes may dominate the incorporation and processing of DOC, and may be a sink, and not a food web link, for carbon in small lakes.

\section{Constructing "flow" food webs that include subsidies}

The most comprehensive approach that we advocate to merge ecosystem and food web approaches to subsidies are flow food webs (hereafter FFW). Although a linkage food web describes who eats whom, a FFW weights the flows between food web members by the amount of organic matter that is required to support consumer production from each food source. A FFW is 
constructed by combining annual production of consumers, proportions of food categories consumed, and assimilation efficiencies for the different food types (or how much consumer biomass is produced per gram of food; Benke and Wallace 1980). The approach explicitly acknowledges that the greatest error is in the estimates of the fluxes, not the estimates of the bioenergetic-based parameters, so most of the sampling effort is directed toward quantifying animal production and diet proportions, while assimilation efficiencies are typically derived from the literature. Although FFWs can be laborintensive to construct, they use assumptions that make them more feasible to complete than IBP-type mechanistic models, while encompassing some of the complexity of food web dynamics. FFWs can range in scope and detail from describing the organic matter flow to a single consumer or suite of consumers (Benke and Wallace 1980, 1997), to very complex webs that span multiple trophic levels and include microbial consumers (Hall et al. 2000; Cross et al., in press).

The strength of FFWs lies in their ability to discern and compare trophic fluxes, providing a common framework to evaluate the importance of quality and quantity of food resources, including subsidies, and simultaneously incorporating dynamics at the level of ecosystem and food web. For example, Hall et al. (2000) constructed a FFW that estimated organic matter flow to detritivorous and predatory macroinvertebrates during a long-term leaf litter exclusion from a stream at the Coweeta Hydrologic Laboratory in the southern Appalachian Mountains (Wallace et al. 1997). Leaf litter and microbes were the largest sources of organic matter to consumers in both streams, but the overall magnitude of organic matter flow through the food web decreased 2.5-3 fold with litter exclusion. Predatory invertebrate production also decreased in the litterexcluded streams and consumption rates per predator biomass increased, suggesting that competitive interactions among predators may increase under reduced subsidy supply. At the ecosystem level, this FFW analysis confirmed the vital importance of leaf litter subsidies for forested headwater stream ecosystems. Moreover, this FFW provided insight into food web dynamics, demonstrating the role of microbes not only as organic matter processors but also as a food web link to detritivorous and predatory invertebrates (Hall and Meyer 1998, Hall et al. 2000), and the potential effects of subsidy reductions on community- and population-level invertebrate interactions (e.g., competition for prey; Hall et al. 2000).

In addition to traditional information on ecosystem or trophic production and food web linkages, FFWs can be used to calculate food web and ecosystem metrics that might be used to test hypotheses in both subdisciplines. Ecosystem ecologists typically calculate efficiencies of energy or organic matter transfer among and within trophic levels (Lindeman 1942, Odum and Barrett 2005). Efficiencies that aggregate across trophic levels, such as trophic level energy intake or production efficiency (Lindeman 1942), can be calculated from FFWs. One may also calculate the efficiency of trophic linkages among specific taxa at different trophic levels using FFWs; this insight may help one to understand why certain trophic linkages appear stronger than others. From a food web perspective, FFWs also may be used to calculate food web metrics such as mean trophic level, food chain length, and interaction strength. Whereas experimental manipulation is the traditional approach to estimate per capita interaction strength (Paine 1980), strengths of interactions can also be estimated in biomass terms by dividing the rate of organic matter flux of a given food resource to a consumer (estimated in a FFW), by the biomass of that resource. Wootton (1997) demonstrated for rocky intertidal animals that consumption-based estimates of interaction strengths were comparable to per capita rates determined experimentally, provided that observations and experiments were expressed over similar timescales. Notably, these biomass- or FFW-based interaction strengths can be estimated in ecosystems where experimental per capita responses cannot be determined, such as in whole-ecosystem experiments. For example, interaction strengths estimated by Hall et al. (2000) demonstrated that predator control of prey was stronger when basal resources were reduced in a whole-stream litter exclusion experiment. Similarly, Cross et al. (in press) recently used this approach to show how experimental flow manipulations of the Colorado River in Glen Canyon affected the strength of interactions between rainbow trout and invertebrate prey.

\section{Conclusion}

The study of resource subsidies in freshwaters has been limited to date by the lack of a cohesive framework for considering the role of diverse subsidies. We have demonstrated that the quality and quantity of a subsidy may mediate its importance for ecosystem processes and food web consumption, and furthermore, that the greatest insight into the importance of subsidies is gained when information on quality and quantity are combined. Only these integrated approaches will allow us to address the next generation of questions regarding resource subsidies: "Are bacteria a "link" or "sink" for allochthonous material respired in freshwaters (Jansson et al. 2007)?"; "What is the relative importance of subsidies to different trophic levels (e.g., nutrient enrichment vs. organic matter vs. prey; Leroux and Loreau 2008)?"; "Why do subsidies induce trophic cascades in some ecosystems, but not in others (Baxter et al. 2005, Marczak et al. 2007)?"; "How do subsidies affect the strength and dynamics of interactions in recipient food webs (Huxel and McCann 1998, Spiller et al. 2010)?"; and "How do temporal and spatial patterns of subsidy delivery alter ecosystem dynamics and stability (Nowlin et al. 2007, Takimoto et al. 2009)?" 
Additionally, although the quality and quantity of the subsidy will set the capacity of that subsidy to affect a recipient ecosystem, the characteristics and preferences of animals in the recipient ecosystem (e.g., foraging behavior, life history, numerical vs. behavioral responses; Baxter et al. 2005, Takimoto et al. 2009) will mediate the realized expression of that subsidy; the effect of animals on the impacts of subsidies deserves its own critical synthesis. Although our analysis has focused on carbon fluxes via organic matter, the same approach could be extended to subsidies and fluxes of other nutrients and materials (e.g., Cross et al. 2007). The strength of the merged ecosystem-food web approach to subsidies may also be used in terrestrial and marine ecosystems (e.g., Polis and Hurd 1995, Gratton and Vander Zanden 2009, Spiller et al. 2010). In conclusion, merged ecosystem and food web approaches provide a common framework for understanding the role of subsidies in the ecology of ecosystems and food webs. These merged approaches are best executed through communication and collaboration among ecologists with complementary expertise and interests in the subfields of ecosystem and community ecology.

\section{ACKNOWLEDGMENTS}

The ideas and syntheses in this paper benefited from interactions with and critiques by many colleagues, especially G. Wayne Minshall, Emma Rosi-Marshall, Kurt Fausch, Masashi Murakami, Mark Wipfli, Wyatt Cross, John Davis, Angus McIntosh, Steve Hamilton, John Stachowicz, Jon Cole, and an anonymous reviewer. This work was funded by the National Science Foundation Idaho EPSCoR (EPS 04-47689, 08-14387) and Ecology (05-16136) programs and a fellowship to A. M. Marcarelli from the Japan Society for the Promotion of Science.

\section{Literature Cited}

Allan, J. D. 1981. Determinants of diet of brook trout (Salvelinus fontinalis) in a mountain stream. Canadian Journal of Fisheries and Aquatic Sciences 38:184-192.

Baxter, C. V., K. D. Fausch, M. Murakami, and P. L. Chapman. 2007. Invading rainbow trout usurp a terrestrial prey subsidy from native charr and reduce their growth and abundance. Oecologia 153:461-470.

Baxter, C. V., K. D. Fausch, and W. C. Saunders. 2005. Tangled webs: reciprocal flows of invertebrate prey link streams and riparian zones. Freshwater Biology 50:201-220.

Bender, E. A., T. J. Case, and M. E. Gilpin. 1984. Perturbation experiments in community ecology: theory and practice. Ecology 65:1-13.

Benke, A. C., and J. B. Wallace. 1980. Trophic basis of production among net-spinning caddisflies in a southern Appalachian stream. Ecology 61:108-118.

Benke, A. C., and J. B. Wallace. 1997. Trophic basis of production among riverine caddisflies: implications for food web analysis. Ecology 78:1132-1145.

Brett, M. T., M. J. Kainz, S. J. Taipale, and H. Seshan. 2009. Phytoplankton, not allochthonous carbon, sustains herbivorous zooplankton production. Proceedings of the National Academy of Sciences USA 106:21197-21201.

Caraco, N. F., and J. J. Cole. 2004. When terrestrial organic matter is sent down the river: The importance of allochthonous $\mathrm{C}$ inputs to the metabolism of lakes and rivers. Pages 301-316 in G. A. Polis, M. E. Power, and G. R. Huxel, editors. Food webs at the landscape level. University of Chicago Press, Chicago, Illinois, USA.
Carpenter, S. R., J. J. Cole, M. L. Pace, M. Van de Bogert, D. L. Bade, D. Bastviken, C. M. Gille, J. R. Hodgson, J. F. Kitchell, and E. S. Kritzberg. 2005. Ecosystem subsidies: terrestrial support of aquatic food webs from ${ }^{13} \mathrm{C}$ addition to contrasting lakes. Ecology 86:2737-2750.

Cole, J. J., S. R. Carpenter, M. L. Pace, M. C. Van de Bogert, J. L. Kitchell, and J. R. Hodgson. 2006. Differential support of lake food webs by three types of terrestrial organic carbon. Ecology Letters 9:558-568.

Cole, J. J., M. L. Pace, S. R. Carpenter, and J. F. Kitchell. 2000. Persistence of net heterotrophy in lakes during nutrient addition and food web manipulation. Limnology and Oceanography 45:1718-1730.

Cross, W. F., C. V. Baxter, K. C. Donner, E. J. Rosi-Marshall, T. A. Kennedy, R. O. Hall. H. A. Wellard Kelly. and R. S. Rogers. 2011. Ecosystem ecology meets adaptive management: food web response to a controlled flood on the Colorado River, Glen Canyon. Ecological Applications 21, in press.

Cross, W. F., J. B. Wallace, and A. D. Rosemond. 2007. Nutrient enrichment reduces constraints on material flows in a detritus-based food web. Ecology 88:2563-2575.

Cummins, K. W. 1974. Structure and function of stream ecosystems. BioScience 24:631-641.

del Giorgio, P. A., J. J. Cole, N. F. Caraco, and R. H. Peters. 1999. Linking planktonic biomass and metabolism to net gas fluxes in northern temperate lakes. Ecology 80:14221431.

del Giorgio, P. A., and R. H. Peters. 1993. Balance between phytoplankton production and plankton respiration in lakes. Canadian Journal of Fisheries and Aquatic Sciences 50:282289.

de Ruiter, P. C., A. M. Neutel, and J. C. Moore. 1995. Energetics, patterns of interaction strengths, and stability in real ecosystems. Science 269:1257-1260.

Dodds, W. K., and J. J. Cole. 2007. Expanding the concept of trophic state in aquatic ecosystems: it's not just the autotrophs. Aquatic Sciences 69:427-439.

Duarte, C. M., and Y. T. Prairie. 2005. Prevalence of heterotrophy and atmospheric $\mathrm{CO}_{2}$ emissions from aquatic ecosystems. Ecosystems 8:862-870.

Finlay, J. C. 2001. Stable-carbon-isotope ratios of river biota: implications for energy flow in lotic food webs. Ecology 82:1052-1064.

Fisher, S. G., and G. E. Likens. 1973. Energy flow in Bear Brook, New Hampshire: an integrative approach to stream ecosystem metabolism. Ecological Monographs 43:421-439.

Gerking, S. D. 1994. Feeding ecology of fish. Academic Press, San Diego, California, USA.

Golley, F. B. 1993. A history of the ecosystem concept in ecology. Yale University Press, New Haven, Connecticut, USA.

Gratton, C., and M. J. Vander Zanden. 2009. Flux of aquatic insect productivity to land: comparison of lentic and lotic ecosystems. Ecology 90:2689-2699.

Hagen, J. B. 1992. An entangled bank: the origins of ecosystem ecology. Rutgers University Press, Princeton, New Jersey, USA.

Hall, R. O., and J. L. Meyer. 1998. The trophic significance of bacteria in a detritus-based stream food web. Ecology 79:1995-2012.

Hall, R. O., J. B. Wallace, and S. L. Eggert. 2000. Organic matter flow in stream food webs with reduced detrital resource base. Ecology 81:3445-3463.

Hotchkiss, E. R., and R. O. Hall. 2010. Linking calcification by exotic snails to stream inorganic carbon cycling. Oecologia 163:235-244.

Huxel, G. R., and K. McCann. 1998. Food web stability: the influence of trophic flows across habitats. American Naturalist 152:460-469. 
Hynes, H. N. B. 1975. The stream and its valley. Verhandlungen der Internationale Vereinigung für Theoretische und Angewandte Limnologie 19:1-15.

Jackson, J. K., and S. G. Fisher. 1986. Secondary production, emergence, and export of aquatic insects of a Sonoran Desert stream. Ecology 67:629-638.

Jansson, M., L. Persson, A. M. De Roos, R. I. Jones, and L. Tranvik. 2007. Terrestrial carbon and intraspecific sizevariation shape lake ecosystems. Trends in Ecology and Evolution 22:316-322.

Junger, M., and D. Planas. 1994. Quantitative use of stable carbon isotope analysis to determine the trophic base of invertebrate communities in a boreal forest lotic system. Canadian Journal of Fisheries and Aquatic Sciences 51:5261.

Karlsson, J. 2007. Different carbon support for respiration and secondary production in unproductive lakes. Oikos 116:1691-1696.

Kawaguchi, Y., Y. Taniguchi, and S. Nakano. 2003. Terrestrial invertebrate inputs determine the local abundance of stream fishes in a forested stream. Ecology 84:701-708.

Kritzberg, E. S., J. J. Cole, M. L. Pace, W. Granéli, and D. L. Bade. 2004. Autochthonous versus allochthonous carbon sources of bacteria: results from whole-lake ${ }^{13} \mathrm{C}$ addition experiments. Limnology and Oceanography 49:588-596.

Lau, D. C. P., K. M. Y. Leung, and D. Dudgeon. 2008. Experimental dietary manipulations for determining the relative importance of allochthonous and autochthonous food resources in tropical streams. Freshwater Biology 53:139-147.

Leroux, S. J., and M. Loreau. 2008. Subsidy hypothesis and strength of trophic cascades across ecosystems. Ecology Letters 11:1147-1156.

Likens, G. E., and F. H. Bormann. 1995. Biogeochemistry of a forested ecosystem. Second edition. Springer, New York, New York, USA.

Lindeman, R. L. 1942. The trophic-dynamic aspect of ecology. Ecology 23:399-417.

Marczak, L. B., R. M. Thompson, and J. S. Richardson. 2007. Meta-analysis: trophic level, habitat, and productivity shape the food web effects of resource subsidies. Ecology 88:140148.

McCutchan, J. H., and W. M. Lewis. 2002. Relative importance of carbon sources for macroinvertebrates in a Rocky Mountain stream. Limnology and Oceanography 47:742752.

Meyer, J. L. 1989. Can P/R ratio be used to assess the food base of stream ecosystems? A comment on Rosenfeld and Mackay 1987. Oikos 54:119-121.

Minshall, G. W. 1967. Role of allochthonous detritus in the trophic structure of a woodland springbrook community. Ecology 48:139-149.

Minshall, G. W. 1978. Autotrophy in stream ecosystems. BioScience 28:767-771.

Mulholland, P. J. 1981. Organic carbon flow in a swampstream ecosystem. Ecology 51:307-322.

Nakano, S., Y. Kawaguchi, Y. Taniguchi, H. Miyasaka, Y. Shibata, H. Urabe, and N. Kuhara. 1999. Selective foraging on terrestrial invertebrates by rainbow trout in a forested headwater stream in northern Japan. Ecological Research 14:351-360.

Nakano, S., and M. Murakami. 2001. Reciprocal subsidies: dynamic interdependence between terrestrial and aquatic food webs. Proceedings of the National Academy of Sciences USA 98:166-170.

Nowlin, W. H., M. J. Gonzales, M. J. Vanni, M. H. H. Stevens, M. W. Fields, and J. J. Valente. 2007. Allochthonous subsidy of periodical cicadas affects the dynamics and stability of pond communities. Ecology 88:2174-2186.

Odum, E. P., and G. W. Barrett. 2005. Fundamentals of ecology. Fifth edition. Thomson Brooks/Cole, Belmont, California, USA.
Odum, H. T. 1956. Primary production in flowing waters. Limnology and Oceanography 1:102-117.

Odum, H. T. 1957. Trophic structure and productivity of Silver Springs, Florida. Ecological Monographs 27:55-112.

Pace, M. L., J. J. Cole, S. R. Carpenter, J. F. Kitchell, J. R. Hodgson, M. C. Van de Bogert, D. L. Bade, E. S. Kritzberg, and D. Bastviken. 2004. Whole-lake carbon-13 additions reveal terrestrial support of aquatic food webs. Nature 427:240-243.

Paine, R. T. 1980. Food webs: linkage, interaction strength and community infrastructure. Journal of Animal Ecology 49:667-685.

Polis, G. A., W. B. Anderson, and R. D. Holt. 1997. Toward an integration of landscape and food web ecology: the dynamics of spatially subsidized food webs. Annual Review of Ecology and Systematics 28:289-316.

Polis, G. A., and S. D. Hurd. 1995. Extraordinarily high spider densities on islands: flow of energy from the marine to terrestrial food webs and the absence of predation. Proceedings of the National Academy of Sciences USA 92:43824386.

Polis, G. A., M. E. Power, and G. R. Huxel, editors. 2004. Food webs at the landscape level. University of Chicago Press, Chicago, Illinois, USA.

Power, M. E., and W. E. Rainey. 2000. Food webs and resource sheds: towards spatially delimiting trophic interactions. Pages 291-314 in M. J. Hutchings, E. A. John, and A. J. A. Stewart, editors. Ecological consequences of habitat heterogeneity. Blackwell Scientific, Oxford, UK.

Reiners, W. A., and K. L. Driese. 2001. The propagation of ecological influences through heterogeneous environmental space. BioScience 51:939-950.

Reynolds, C. S. 2008. A changing paradigm of pelagic food webs. International Review of Hydrobiology 93:517-531.

Roberts, B. J., P. J. Mulholland, and W. R. Hill. 2007. Multiple scales of temporal variability in ecosystem metabolism rates: results from 2 years of continuous monitoring in a forested headwater stream. Ecosystems 10:588-606.

Rosenfeld, J. S., and R. J. Mackay. 1987. Assessing the food base of stream ecosystems: alternatives to the $\mathrm{P} / \mathrm{R}$ ratio. Oikos 50:141-147.

Shibata, H., H. Mitsuhashi, Y. Miyako, and S. Nakano. 2001. Dissolved and particulate carbon dynamics in a cooltemperate forested basin in northern Japan. Hydrological Processes 15:1817-1828.

Spiller, D. A., J. Piovia-Scott, A. N. Wright, L. H. Yang, G. Takimoto, T. W. Schoener, and T. Iwata. 2010. Marine subsidies have multiple effects on coastal food webs. Ecology 91:1424-1434.

Takimoto, G., T. Iwata, and M. Murakami. 2003. Seasonal subsidy stabilized food web dynamics: balance in a heterogeneous landscape. Ecological Research 17:433-439.

Takimoto, G., T. Iwata, and M. Murakami. 2009. Timescale hierarchy determines the indirect effects of fluctuating subsidy inputs on in situ resources. American Naturalist 173:200-211.

Thorp, J. H., and M. D. Delong. 1994. The riverine productivity model: an heuristic view of carbon sources and organic processing in large river ecosystems. Oikos 70:305308.

Thorp, J. H., and M. D. Delong. 2002. Dominance of autochthonous autotrophic carbon in food webs of heterotrophic rivers. Oikos 96:543-550.

Vadeboncoeur, Y., D. M. Lodge, and S. R. Carpenter. 2001. Whole-lake fertilization effects on distribution of primary production between benthic and pelagic habitats. Ecology 82:1062-1077.

Vander Zanden, M. J., and Y. Vadeboncoeur. 2002. Fishes as integrators of benthic and pelagic food webs in lakes. Ecology 83:2152-2161. 
Wallace, J. B., S. L. Eggert, J. L. Meyer, and J. R. Webster. 1997. Multiple trophic levels of a forest stream linked to terrestrial litter inputs. Science 277:102-104.

Webster, J. R., and E. F. Benfield. 1986. Vascular plant breakdown in freshwater ecosystems. Annual Review of Ecology and Systematics 17:567-594.

Webster, J. R., and J. L. Meyer. 1997. Stream organic matter budgets. Journal of the North American Benthological Society 16:3-161.

Wetzel, R. G. 1995. Death, detritus, and energy flow in aquatic ecosystems. Freshwater Biology 33:83-89.

Wetzel, R. G. 2001. Limnology. Third edition. Academic Press, San Diego, California, USA.

Wiegert, R. G., and D. F. Owen. 1971. Trophic structure, available resources and population density in terrestrial vs. aquatic ecosystems. Journal of Theoretical Biology 30:69-81.
Winter, T. C., and G. E. Likens, editors. 2009. Mirror Lake: interactions among air, land and water. University of California Press, Berkeley, California, USA.

Wipfli, M. W. 1997. Terrestrial invertebrates as salmonid prey and nitrogen sources in streams: contrasting old-growth and young-growth riparian forests in southeastern Alaska, U.S.A. Canadian Journal of Fisheries and Aquatic Sciences 54:1259-1269.

Wipfli, M. W., and C. V. Baxter. 2010. Linking ecosystems, food webs, and fish production: subsidies in salmonid watersheds. Fisheries 35:373-387.

Wootton, T. J. 1997. Estimates and test of per capita interaction strength: diet, abundance, and impact of intertidally foraging birds. Ecological Monographs 67:45-64.

Yang, L. H., K. F. Edwards, J. E. Byrnes, J. L. Bastow, A. N. Wright, and K. O. Spence. 2010. A meta-analysis of resource pulse-consumer interactions. Ecological Monographs $80: 125-151$.

\section{APPENDIX A}

Methods used in the literature review of open-water metabolism, a table of studies included in the review, and comparisons of GPP:ER vs. environmental factors in lakes and streams (Ecological Archives E092-101-A1).

\section{APPENDIX B}

Methods and a table of studies used in the literature review of subsidy quality and use (Ecological Archives E092-101-A2).

\section{APPENDIX C}

Table of studies that integrate ecosystem and food web responses to determine the importance of resource subsidies to freshwaters (Ecological Archives E092-101-A3).

\section{APPENDIX D}

Table of studies and rates used in the comparison of ecosystem respiration vs. secondary production in streams and lakes (Ecological Archives E092-101-A4). 